\title{
SOSIALISASI INTELLIGENT RESEARCH AND INNOVATION SERVICES (IRIS) 1103 BAGI CIVITAS AKADEMIKA UNS \\ (Studi Evaluasi Model CIPP terhadap Sosialisasi IRIS1103 oleh Lembaga Penelitian dan Pengabdian kepada Masyarakat Universitas Sebelas Maret)
}

\author{
Sri Suranti*), Sutopo JK ${ }^{* *}$, Sri Hastjarjo ${ }^{* *}$ \\ *) Mahasiswa Pascasarjana UNS Program Ilmu Komunikasi; Tenaga Kependidikan UNS; rantisaputro@ymail.com \\ **) Dosen Pascasarjana UNS Program Ilmu Komunikasi
}

\begin{abstract}
The objectives of this research to evaluate the success of socialization activities IRIS1103 organized by LPPM UNS for civitas akademika UNS based on CIPP evaluation model, supported quantitative and qualitative data. Quantitative data are collected using questionnaires given to educators in the environment UNS. While qualitative data obtained through interviews with researchers and implementers of the target IRIS1103 and socialization study documents used in the activities of socialization.

Based on the results of the CIPP evaluation model (Context, Input, Process, Product) on the communication element (Communicator, message, and partisipant) in the IRIS1 103 socialization activities be declared successful and effective way to improve understanding and knowledge of civitas akademika UNS about Groove Research and community services (P2M) IRIS1103 in the application which ultimately encourage them to create new routines, visit iris1103.uns.ac.id every page requires information on the P2M.
\end{abstract}

Key words: socialization, CIPP evaluation model, IRIS1103, research and community services

\section{PENDAHULUAN}

Kegiatan sosialisasi menjadi salah satu pilihan bentuk aktivitas penyebaran informasi yang 'lumrah' diselenggarakan di instansi pemerintahan untuk memperkenalkan dan menyebarluaskan agenda/program kerja, hasil kerja, peraturan terbaru, dan sebagainya yang ditujukan kepada khalayaknya agar dapat berpartisipasi aktif sebagai anggota kelompok/institusi tersebut seperti yang diharapkan pemimpin kelompok/institusi.

Joseph R. Dominick dalam Effendy (2003: 31) memperkuat eksistensi sosialisasi dalam ruang lingkup komunikasi sebagai alat yang memfasilitasi kegiatan transmisi nilainilai (transmission of value) yang mengacu pada cara-cara dimana seseorang mengadopsi perilaku dan nilai-nilai dari suatu kelompok.

Pada tataran ini komunikasi menjadi bagian integral dari masyarakat. Sedangkan kegiatan sosialisasi merupakan kegiatan komunikasi yang ditandai dengan adanya proses penyebaran pengetahuan dari seorang penyuluh (komunikator) kepada masyarakat sasaran (komunikan) dengan tujuan meningkatkan pengetahuan yang berkaitan dengan konteks permasalahan yang dihadapi khalayak masyarakat. Hal ini menandakan bahwa sosialisasi memegang peranan di dalam menyebarluaskan berbagai informasi salah satunya berkaitan dengan inovasi atau pengetahuan-pengetahuan yang berhubungan 
dengan inovasi, baik pengetahuan teknis maupun pengetahuan praktis.

Sedangkan bagi sebuah organisasi, perilaku berkomunikasi tidak dapat dipisahkan.Individu-individu dalam organisasi beraksi, berinteraksi dan berkomunikasi untuk menentukan tujuan yang ingin dicapai organisasi, menyusun rencana kerja, memperlancar pelaksanaan rencana kerja, menyusun peraturan, mengambil keputusan, memonitor kinerja organisasi, dan berhubungan dengan pihak-pihak di luar organisasi. Dengan kata lain, organisasi ditandai oleh unit-unit komunikasi yang terjalin secara hierarki dalam hubunganhubungan antar individu di dalamnya dan berfungsi pada lingkungan tertentu (Pace, 2013:31).

Di dalam sebuah organisasi, komunikasi yang efektif memegang peranan penting untuk menentukan kelangsungan hidup serta kesehatan organisasi.Segala kegiatan baik interaksi maupun saling ketergantungan antar anggota organisasi berlangsung atas dasar komunikasi, dan hanya dengan komunikasi pengaruh atas perilaku individu dapat terjadi.Karena komunikasi merupakan inti dari sistem sosial atau organisasi itu sendiri. Dengan demikian, penyelenggaraan sistem komunikasi yang efektif menjadi keharusan bagi setiap organisasi (Harjana, 2000:x). Dalam konteks penelitian ini, komunikasi organisasi yang terjadi akan terlihat pada proses penyebaran informasi yang dilakukan setiap anggota organisasi.

\section{Intelligent Research and Innovation} Services (IRIS)1103 yang dikembangkan Lembaga Penelitian dan Pengabdian kepada Masyarakat Universitas Sebelas Maret (LPPM UNS) merupakan inovasi yang ditujukan kepada civitas akademika UNS terutama tenaga pendidik di lingkungan UNS yang melakukan aktivitas Penelitian dan Pengabdian kepada Masyarakat (P2M). Inovasi ini bermanfaat untuk mengelola berbagai aktivitas P2M setiap dosen atau peneliti di UNS sehingga menghasilkan basis data berupa rekam jejak P2M yang baik dan terintegrasi yang dapat digunakan sebagai pengisian data kinerja Perguruan Tinggi di simlitabmas.go.id, basis data perankingan UNS baik secara nasional ataupun internasional serta dasar pembayaran remunerasi tenaga pendidik UNS.

Sebagai sebuah inovasi, IRIS1103 sangat perlu diperkenalkan kepada tenaga pendidik di lingkungan UNS sebagaiuser. Pada tahun 2013 hingga saat ini, IRIS1103 diperkenalkan LPPM UNS kepada publik sasarannya dengan berbagai penambahan pada aplikasinya yang disesuaikan dengan pedoman atau panduan pelaksanaan P2M melalui kegiatan sosialisasi.

Selama kurun waktu tersebut LPPM UNS sebagai pihak pengembang IRIS1103 dan penyelenggara kegiatan sosialisasi IRIS1103 belum pernah melakukan evaluasi.Sehingga tingkat keberhasilan atau efektivitas dari pelaksanaan kegiatan sosialisasi IRIS1103 belum diketahui oleh pelaksana sosialisasi.

Menurut Daniel L. Stufflebeam "evaluation is the process of delineating, obtaining, reporting, and applying descriptive and judgmental information about some object's merit, worth, probity and significance in order to guide decision making, support accountability, disseminate effective practices, and increase understanding of involved phenomena" (Wirawan, 2012:7)

Evaluasi dimaknai sebagai proses melukiskan, memperoleh dan menyediakan informasi yang berguna untuk menilai alternatif-alternatif pengambilan keputusan. Dalam hal ini melukiskan dimaknai 
menspesifikasi, mendefinisi dan menjelaskan untuk memfokuskan informasi yang diperlukan oleh pengambil keputusan.Memperoleh artinya memakai pengukuran dan statistik untuk mengumpulkan, mengorganisasi dan menganalisis informasi. Sedangkan menyediakan berarti mensintesiskan informasi sehingga akan melayani dengan baik kebutuhan evaluasi para pemangku kepentingan evaluasi. Sehingga dengan melakukan evaluasi faktor-faktor yang menghambat dan mendorong kegiatan sosialisasi dapat diketahui.

Oleh karena itu, penelitian ini dilakukan untuk mengetahui tingkat keberhasilan atau efektivitas serta faktor pendukung dan penghambat pelaksanaan kegiatan sosialisasi IRIS1103 yang diselenggarakan oleh LPPM UNS kepada civitas akademika UNS.

\section{METODE PENELITIAN}

Penelitian ini menggunakan metodologi penelitian campuran antara kualitatif dan kuantitatif yang bersifat evaluatif.Meskipun riset ini menggunakan multiple methode antara kualitatif dan kuantitatif, namun pengumpulan dan penyajian data dilakukan secara kualitatif dimana diperoleh data deskriptif tentang objek kajian yang diamati.Data-data kuantitatif yang dihasilkan hanya sebagai pendukung data-data kualitatif, dimana data kuantitatif yang berupa angka tidak dipaksakan untuk membuktikan sebuah prediksi atau hipotesis tapi digunakan sebagai penunjang analisis kualitatif yang lebih menekankan kemantapan makna sebagai simpulan akhir penelitian.

Dengan demikian riset ini tidak menekankan pada kedalaman variabel atau pembuktian hipotesis yang merupakan pondasi kuantitatif, aspek kuantitatif berlangsung hanya pada tahap penggalian data berupa kuesioner yang bertujuan mengukur efektivitas kegiatan sosialisasi yang dilakukan LPPM UNS terhadap program IRIS 1103 kepada civitas akademika UNS. Sehingga peneliti dapat memperoleh data atau informasi bahwa kegiatan sosialisasi yang telah diselenggarakan tersebut efektif atau tidak. Sedangkan aspek kualitatif pada penelitian ini akan berlangsung dalam kegiatan wawancara dimana data atau informasi mengenai proses komunikasi dalam kegiatan sosialisasi IRIS 1103 beserta faktor pendukung dan penghambatnya dapat terdeskripsi secara eksplisit.

Selain itu berdasarkan tataran atau cara menganalisis data, penelitian ini akan dikaji secara evaluatif dengan menggunakan pendekatan model CIPP yang dikemukakan oleh Stufflebeam yang terdiri dari empat komponen evaluasi, yakni context evaluation, input evaluation, process evaluation, product evaluation.Penelitian juga termasuk penelitianevaluasi formatif, dimana evaluasi yang dilakukan saat kegiatan/program sedang berjalan sehingga hasil evaluasi bermanfaat untuk memperbaiki atau meningkatkan kualitas kegiatan/program.

\subsection{Pelaksana Sosialisasi IRIS1103}

Tenaga Kependidikan LPPM UNS yang bertugas di Sub Bagian Program dan Kerjasama serta Sub Bagian Data Informasi merupakan pelaksana kegiatan sosialisasi IRIS1103.Kedua Sub Bagian di lingkungan LPPM UNS tersebut mengelola berbagai kegiatan P2M dari tahap awal hingga akhir serta luaran $\mathrm{P} 2 \mathrm{M}$.

Adapun informan yang menjadi sasaran penelitian yaitu 3 staf kependidikan Sub Bagian Program dan Kerjasama dan 1 staf kependidikan Sub Bagian Data Informasi LPPM UNS. Mereka merupakan pelaksana lapangan yang bertugas mempersiapkan 
penyelenggaraan kegiatan sosialisasi IRIS1 103 bagi civitas akademika UNS.

\subsection{Sasaran Sosialisasi IRIS1103}

Sasaran kegiatan sosialisasi IRIS1103 adalah seluruh tenaga pendidik atau dosen di lingkungan UNS yang melakukan kegiatan P2M dari berbagai skema yang ditawarkan berbagai lembaga pemberi hibah. Secara purposive dibagi dalam dua kategori berdasarkan metodologi penelitian yang digunakan peneliti, subyek penelitian pertama merupakan dosen UNS sebanyak 94 orang yang dimintai respon mengenai pelaksanaan kegiatan sosialisasi IRIS melalui questioner yang dibagikan secara random yang bertujuan memperoleh data kuantitatif. Sedangkan 9 orang informan dosen yang menduduki jabatan tertentu baik di LPPM maupun Fakultas diwawancarai secara mendalam untuk memperoleh data kualitatif.

\section{Keberhasilan atau Efektivitas Sosialisasi IRIS1103 Ditinjaudari Aspek Konteks, Input, Proses Dan Produk}

Kegiatan sosialisasi IRIS1103 yang dilaksanakan LPPM UNS kepada civitas akademika UNS bertujuan membangun pengetahuan dan pemahaman para tenaga pendidik dan peneliti di lingkungan UNS mengenai IRIS110 sehingga mereka tahu dan pahamkhususnya pemanfaatan aplikasi tersebut dalam kegiatan P2M.Pada konteks komunikasi organisasi, proses penyebaran informasi IRIS1103 tersebut dilakukan dalam berbagai bentuk kegiatan komunikasi secara berurutan (Guetzkow dalam Pace, 2013: 172).Dalam hal ini, sumber pesan (Sekretaris LPPM dan Tim IRIS1103) memberikan informasi IRIS1103 kepada para dekan, ketua program studi, KPPMF/KPPMP, ketua pusat studi LPPM serta tenaga kependidiksn LPPM UNS. Selanjutnya, mereka menyelenggarakan sosialisasi secara mandiri kepada para tenaga pendidik dan peneliti di fakultas dan unit kerja masing-masing.Proses penyebaran pesan/informasi mengenai IRIS1103 dapat dicermati dari grafik berikut:

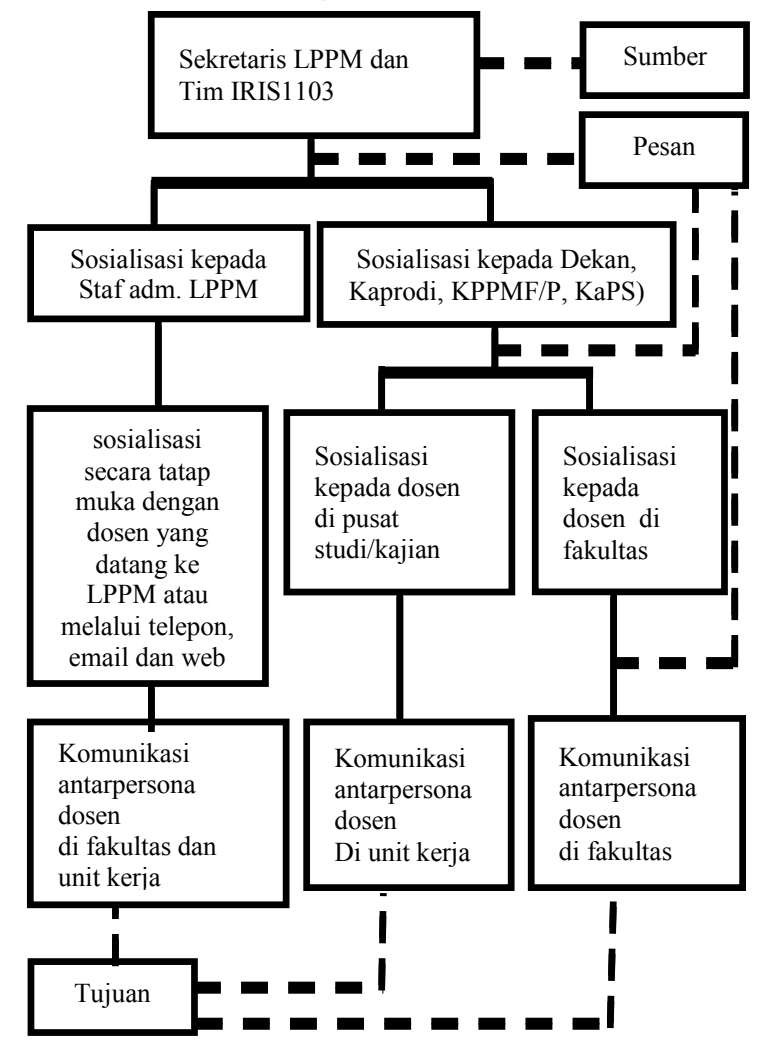

Grafik 1. Penyebaran pesan IRIS1103 secara berurutan

Grafik 1 di atas menggambarkan alur penyebaran pesan yang dilakukan secara berurutan sesuai dengan kedudukan hirerarki setiap anggota dalam sebuah organisasi.Di sini setiap orang kecuali orang pertama sebagai sumber pesan, melakukan interpretasi pesan yang diterima yang selanjutnya hasil interpretasi tersebut diteruskan kepada orang berikutnya dalam rangkaian tersebut.

Penyebaran pesan secara berurutan mengakibatkan penyebaran informasi berlangsung dalam waktu yang tidak beraturan, tiba di tempat berbeda dan pada waktu yang berbeda. Hal ini dikarenakan adanya proses yang berurutan, dan perbedaan 
individu yang cenderung berbeda dalam menyadari informasi.

Adapun keberhasilan atau tingkat efektivitas kegiatan sosialisasi IRIS1103 yang dilaksanakan LPPM UNS berdasarkan model evaluasi CIPP pada elemen komunikasi (komunikator, pesan dan komunikan) hasilnya adalah sebagai berikut:

\subsection{Aspek Konteks}

Keberhasilan atau efektivitas sosialisasi yang ditinjau pada aspek konteks kegiatan berkaitan erat dengan latar belakang pelaksanaan program kegiatan, tujuan, dan perencanaan program kegiatan.Sosialisasi IRIS1103 dilaksanakan LPPM UNS kepada civitas akademika UNS terutama tenaga pendidik yang mengimplementasikan aktivitas $\mathrm{P} 2 \mathrm{M}$, untuk memperkenalkan inovasi teknologi informasi tata kelola P2M yang baik dan terintegrasi.

Guna mewujudkan tujuan tersebut yakni agar sasaran sosialisasi atau komunikan mengenal dan tahu apa itu IRIS1103, bagaimana pengoperasiannya dan apa kemanfaatanya perlu penyusunan dan perancangan media atau sarana yang digunakan dalam proses komunikasi atau sosialisasi, salah satunya pesan. Dalam hal ini pesan berisi informasi mengenai aplikasi IRIS1103 yang harus mudah dimengerti, dipahami dan dimaknai.Sehingga tidak menimbulkan kebingungan dalam diri komunikan.

Pesan yang efektif dapat dicermati dari 3 dimensi yang membangunnya yakni (1) Bentuk/organisasi pesan, (2) simbol dan (3) makna pesan (Mulyana, 2010:70). Dari analisis data kuantitatif yang diperoleh peneliti, menyatakan bahwa pesan yang dirancang dan disusun oleh pelaksana sosialisasi IRIS1103 sangat efektif menunjang tercapainya tujuan sosialisasi IRIS1103 (tabel
1).Hal tersebut dikarenakan bentuk/organisasi pesan yang disajikan dalam sosialisasi IRIS1103 sangat menarik dan sangat mudah dipahami audience, simbol pesan yang disampaikan narasumber pada sosialisasi IRIS1103 sangat mudah dipahami komunikanserta pesan yang disampaikan oleh narasumber sangat mudah dimaknai.

\begin{tabular}{|l|r|r|}
\hline Kategori & Frek & \multicolumn{1}{|c|}{$\%$} \\
\hline Sangat Rendah & 0 & 0.0 \\
\hline Rendah & 0 & 0.0 \\
\hline Sedang & 13 & 13.8 \\
\hline Tinggi & 72 & 76.6 \\
\hline Sangat Tinggi & 9 & 9.6 \\
\hline Total & $\mathbf{9 4}$ & $\mathbf{1 0 0 . 0}$ \\
\hline
\end{tabular}

Tabel 1 Variabel Pesan $(\mathrm{N}=94)$

\subsection{Aspek Input}

Komponen input atau masukan pada pelaksanaan sebuah kegiatan berkaitan dengan sumber daya baik softwaremaupun hardware yang digunakan. Sumber daya software berupa sumber daya manusia yang melaksanakan dan terlibat dalam sebuah kegiatan.Sedangkan sumber daya hardware berhubungan dengan sarana dan prasarana yang dimanfaatkan secara optimal untuk mendukung keberhasilan sebuah kegiatan.

Terutama software, sumber daya manusia yang terlibat dalam penyelenggaraan sosialisasi IRIS1103 dibedakan menjadi 2 kelompok yakni pelaksana dan narasumber.

Narasumber merupakan personil pelaksana sosialisasi yang memiliki peran menyampaikan informasi atau pesan kepada audience. Narasumber sosialisasi IRIS1103 adalah orang-orang yang memiliki kedudukan internal di LPPM UNS maupun dalam tim pengembangan aplikasi IRIS1103. Narasumber bertanggungjawab membangun pengetahuan dan pemahaman audience 
sosialisasi IRIS1103 terhadap aplikasi tersebut.

Oleh karena itu dibutuhkan peran komunikator/narasumber yang tepat untuk menyampaikan suatu kebijakan dengan syarat mempunyai itikad baik (good intentions), kelayakan untuk dipercaya (truthworthiness) dan kecakapan atau keahlian (Rosfiantika dkk, 2015:285).

Selain itu, narasumber juga harus memiliki kecakapan untuk mengorganisir, membimbing dan menggerakkan audience serta memiliki kemampuan sebagai sumber informasi (Suprapto dan Fahrianoor, 2004:7374).

Dengan kata lain kredibilitas narasumber secara internal ataupun eksternal menjadi modal utama pelaksanaan kegiatan sosialisasi yang seimbang tanpa hambatan. Kredibilitas komunikator mencakup kualitas diri pelaku komunikasi seperti keahlian dan kelayakan yang dimiliki dalam suatu bidang tertentu, kepercayaan komunikan terhadap maksud dan tujuan komunikator serta kepercayaan terhadap posisi atau status komunikator murni sebagai pembicara dan bukan alasan yang menguntungkan dirinya sendiri.

Hal tersebut sejalan dengan Rakhmat (2002: 73-75) yang mengungkapkan bahwa kredibilitas komunikator yang dapat mendukung keberhasilan kegiatan sosialisasi dapat dilihat dari beberapa hal atau dimensi berikut: (1) Otoritas; (2) Good sense; (3) Good character; (4) Good will; (5) Dinamisasi.

Dimensi kredibilitas tersebut dimiliki narasumber dan disampaikan secara tidak langsung ketika melaksanakan kegiatan sosialisasi IRIS1103 kepada audience yakni civitas akademika UNS memegang peranan yang signifikan untuk mengefektifkan kegiatan pengenalan IRIS1103Selain dari kelima dimensi tersebut, kredibilitas komunikator sosialisasi IRIS1103 juga dapat dicermati dari tingkat pendidikan, masa kerja dan fokus bidang kerja yang sesuai dengan materi yang disosialisasikan.

Komunikator atau narasumber sosialisasi IRIS1103 diapresiasi sangat tinggi oleh audience(tabel 2).

\begin{tabular}{|l|r|r|}
\hline Kategori & \multicolumn{1}{|c|}{ Frek } & \multicolumn{1}{c|}{$\%$} \\
\hline Sangat & 0 & 0.0 \\
Rendah & 0 & 0.0 \\
\hline Rendah & 17 & 18.1 \\
\hline Sedang & 69 & 73.4 \\
\hline Tinggi & 8 & 8.5 \\
\hline Sangat Tinggi & $\mathbf{9 4}$ & $\mathbf{1 0 0 . 0}$ \\
\hline Total & & \\
\hline
\end{tabular}

Tabel 2 Variabel Komunikator $(\mathrm{N}=94)$

Audience mengakui narasumber atau komunikator sosialisasi IRIS1103 berkredibilitas di bidangnya dan cakap untuk menyampaikan pesan atau informasi mengenai IRIS1103, memiliki tingkat pendidikan di atas rata-rata, masa kerja yang cukup lama di bidang P2M serta memiliki pengetahuan dan ketrampilan di bidang teknologi informasi atau melek digital.

Sehingga dapat pula dinyatakan bahwa penetapan komponen input dalam pelaksanaan kegiatan sosialisasi IRIS1103 sangat tepat dan maksimal untuk menunjang keberhasilan kegiatan tersebut.

\subsection{Aspek Proses}

Kegiatan sosialisasi IRIS1103 yang dicermati dari penilaian proses dilakukan dalam berbagai bentuk komunikasi baik langsung (direct) maupun tidak langsung (indirect). Sosialisasi yang langsung dilakukan LPPM UNS antara lain: (1) Penyuluhan atau komunikasi kelompok yang 
diselenggarakan baik di LPPM ataupun di Fakultas, (2) Sosialisasi secara antarpersona yakni memberikan informasi face to face kepada dosen yang datang langsung ke LPPM, (3) Melalui komunikasi getok tular, yang terjadi saat dosen berinteraksi atau bergaul dengan rekan sejawatnya. Sedangkan sosialisasi tidak langsung dilakukan LPPM UNS adalah dengan persuratan dan melalui web baik http://lppm.uns.ac.id atau pun http://iris1103.uns.ac.id. Bentuk atau pola komunikasi yang dilaksanakan tersebut bervariasi karena bila hanya mengandalkan satu varian bentuk komunikasi dikhawatirkan tujuan dari sosialisasi tidak terwujud secara optimal dimana respon sasaran atau peserta sosialisasi tidak langsung atau tertunda.

Hal ini juga diungkapkan Effendy (2004: 31) bahwa bentuk atau pola komunikasi yang dapat menciptakan dampak/efek tertentu pada khalayak terjadi pada: (1) Komunikasi tatap muka (face to face)/komunikasi langsung (direct communication), bersifat dua arah timbal balik (two way reciprocal communication) dimana proses komunikasi berlangsung antara komunikator dan komunikan yang saling berhadapan dan saling melihat. Sehingga dapat menimbulkan arus balik seketika.pola komunikasi ini sangat signifikan untuk mengubah sikap, pendapat, dan perilaku komunikan, (2) Komunikasi bermedia (mediated communication)/komunikasi tidak langsung (indirect communication), menggunakan saluran atau sarana untuk meneruskan suatu pesan kepada komunikan yang jauh tempatnya, dan atau banyak jumlahnya dimana ditandai dengan tertunda atau tidak terjadi arus balik pada saat komunikasi dilancarkan. Contohnya: persuratan, telepon, web, email dan lain-lain.

Dua pola atau bentuk komunikasi yang bervariasi dan dilaksanakan LPPM UNS perlu persiapan dan perencanaan yang lebih matang baik oleh komunikator atau narasumber, pesan atau informasi dan sasaran atau komunikannya, sehingga dapat menciptakan kesepahaman antara komunikator dan komunikan terhadap pesan yang dipertukarkan serta memunculkan efek yang merupakan representasi dari keberhasilan proses komunikasi. Seperti alur pada 5 komponen komunikasi yang diformulasikan Harold D Lasswell dalam Ardianto dan Erdinaya (2004: 32-33), yakni “Who-Says What- In Which Cannel-To Whom-With What Effect".

\subsection{Aspek Produk}

Keberhasilan sosialisasi IRIS1103 ditinjau dari aspek Produk atau hasil kegiatan menunjukkan bahwa pasca sosialisasi IRIS1103 ada fenomena-fenomena yang terjadi, diantaranya (1) Kuantitas pengusul riset yang terdaftar di laman iris1103.uns.ac.id mengalami progresifitas yang juga sejalan dengan peningkatan Kuantitas proposal yang masuk di laman iris1103.uns.ac.id, (2) Kuantitas ketua riset grup melakukan update profil riset grup di laman iris1103.uns.ac.id semakin meningkat (Grafik2).

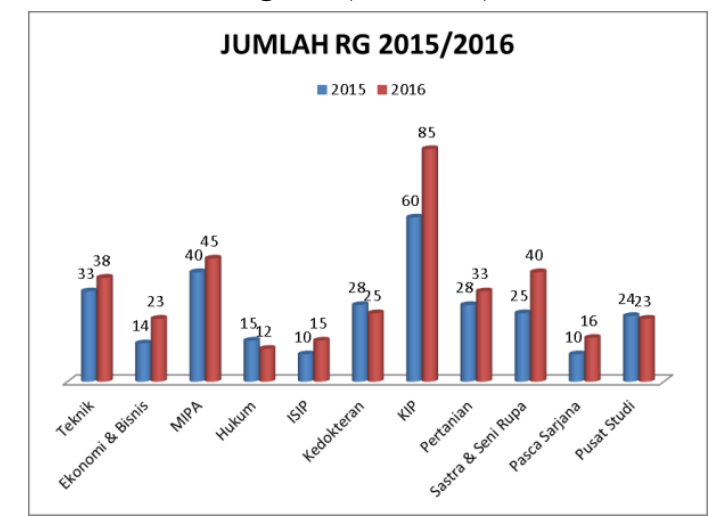

Grafik 2. Progresivitas Kuantitas RG 2015/2016

Progresifitas tersebut menandakan bahwa dalam diri audience sosialisasi IRIS1103 ada pergerakan setelah menerima 
informasi atau pesan mengenai IRIS1103 dalam kegiatan sosialisasi. Mereka mulai tahu dan memahami apa itu IRIS1103, bagaimana pengoperasiannya dan apa manfaatnya. Selanjutnya, mereka mulai mencoba mengunjungi laman iris1103.uns.ac.id, mencermati informasi-informasi yang ada pada laman tersebut.Dan, menggunakan informasi tersebut sesuai dengan kebutuhan setiap aktivitas $\mathrm{P} 2 \mathrm{M}$.

Keberhasilan sosialisasi IRIS1103 dari komponen produk juga dapat dicermati dari analisis data kuantitatif pada dimensi kognitif, afeksi maupun behavior pada diri komunikan pasca sosialisasi.

Pada dimensi kognitif, pengetahuan dan pemahaman audience menjadi semakin tinggi bila dibandingkan saatawal pelaunchingan IRIS1103 dimana mayoritas audience tidak tahu dan paham mengenai aplikasi IRIS1103 namun setelah sosialisasi mereka menjadi lebih tahu dan paham.

\begin{tabular}{|l|r|r|}
\hline Kategori & \multicolumn{1}{|c|}{ Frek } & \multicolumn{1}{|c|}{$\%$} \\
\hline Sangat Rendah & 0 & 0.0 \\
\hline Rendah & 1 & 1.1 \\
\hline Sedang & 12 & 12.8 \\
\hline Tinggi & 73 & 77.7 \\
\hline Sangat Tinggi & 8 & 8.5 \\
\hline Total & $\mathbf{9 4}$ & $\mathbf{1 0 0 . 0}$ \\
\hline
\end{tabular}

Tabel 3 Dimensi Kognisi (N=94)

Pada Dimensi afeksi, kesadaran komunikan tentang IRIS1103 juga semakin meningkat atau tinggi (tabel 3).Mereka lebih dapat menerima aplikasi IRIS1103 pada setiap aktivitas P2M dengan senang hati dan tidak merasa bingung lagi bila harus merekam setiap aktivitas P2M di laman iris1103.uns.ac.id ataupun mencari informasi mengenai tawaran hibah P2M. Hal ini berbanding terbalik dengan sikap atau kesadaran mereka tentang IRIS1103 di saat awal pelaunchingan aplikasi tersebut, mereka lebih sensitif, lebih cepat marah dan selalu kebingungan bila harus berhadapan dengan aplikasi IRIS1103.

\begin{tabular}{|l|r|r|}
\hline Kategori & \multicolumn{1}{|c|}{ Frek } & \multicolumn{1}{c|}{$\%$} \\
\hline Sangat Rendah & 0 & 0.0 \\
\hline Rendah & 3 & 3.2 \\
\hline Sedang & 52 & 55.3 \\
\hline Tinggi & 36 & 38.3 \\
\hline Sangat Tinggi & 3 & 3.2 \\
\hline Total & $\mathbf{9 4}$ & $\mathbf{1 0 0 . 0}$ \\
\hline
\end{tabular}

Tabel 4Dimensi Afeksi (N=94)

Pada perilaku atau behavior komunikan sosialisasi IRIS1103 juga mengalami perubahan yang signifikan.Para audience atau komunikan menyatakan tingkat perubahan perilaku atau behavior mereka terhadap aplikasi IRIS1103 sangat tinggi.Komunikan mulai sering dan atau selalu mengunjungi laman iris1103.uns.ac.id untuk mendapatkan informasi mengenai $\mathrm{P} 2 \mathrm{M}$ dari tahap awal yakni penawaran hibah P2M hingga tahap akhir pelaporan luaran atau hasil $\mathrm{P} 2 \mathrm{M}$.

\begin{tabular}{|l|r|r|}
\hline Kategori & \multicolumn{1}{|c|}{ Frek } & \multicolumn{1}{|c|}{$\%$} \\
\hline Sangat Rendah & 0 & 0.0 \\
\hline Rendah & 4 & 4.3 \\
\hline Sedang & 22 & 23.4 \\
\hline Tinggi & 61 & 64.9 \\
\hline Sangat Tinggi & 7 & 7.4 \\
\hline Total & $\mathbf{9 4}$ & $\mathbf{1 0 0 . 0}$ \\
\hline
\end{tabular}

Tabel 5 Dimensi Behavior ( $\mathrm{N}=94)$

Dengan demikian dapat dikatakan bahwa sosialisasi IRIS1103 berhasil dan efektif bila ditinjau dari komponen produk yang tolok ukurnya adalah perubahan kognisi, afeksi serta behavior dari komunikan setelah 
memperoleh sosialisasi IRIS1103 baik langsung maupun tidak langsung.

\section{Faktor-faktor Pendukung dan Penghambat Sosialisasi IRIS1103}

Keberhasilan pelaksanaan sosialisasi IRIS1103 tidak luput dari hal-hal atau faktorfaktor pendukung dan penghambat proses sosialisasi itu sendiri baik sebelum maupun sesudahnya.

\subsection{Faktor Pendukung Internal}

a. Sumber daya Manusia yang handal dan terpercaya baik sebagai penyelenggara atau pelaksana teknis maupun sebagai narasumber.

b. Didukung oleh sarana prasarana dan pendanaan yang cukup memadai.

c. Pemilihan dan penyusunan pesan dari komunikator kepada komunikan sangat tepat mempermudah pemahaman mereka mengenai IRIS1103.

d. Berdasarkan prosesnya, sosialisasi dilakukan dalam berbagai bentuk atau pola baik secara langsung maupun tidak langsung untuk mengoptimalkan upaya memperkenalkan IRIS1103 kepada civitas akademika UNS.

\subsection{Faktor Pendukung Eksternal}

a. Tingkat pemahaman komunikan sosialisasi IRIS1103 yang cukup tinggi terhadap informasi mengenai aplikasi IRIS1103 yang disampaikan narasumber.

b. Adanya dukungan dari pemangku kepentingan di UNS, mendorong tenaga pendidik di lingkungan UNS untuk mengoptimalkan pemanfaatan IRIS1103.

\subsection{Faktor Penghambat Internal}

a. Aplikasi IRIS1103 yang dibuat tim pendesain IRIS1103 masih kurang lengkap dan terus mengalami penambahan. Hal ini berimplikasi pada penyampaian informasi mengenai
IRIS1103 yang terbatas atau terpotongpotong.

b. Perencanaan awal kegiatan sosialisasi IRIS1103 belum tersusun secara baik dan sistematis dengan mengacu pada analisis situasi (strengthness, weakness, opportunity and treat).

\subsection{Faktor Penghambat Eksternal}

a. Tingkat partisipasi atau kehadiran tenaga pendidik di lingungan UNS dalam kegiatan sosialisasi IRIS1103 masih rendah terutama sosialisasi yang dilaksanakan dalam bentuk komunikasi kelompok di LPPM UNS ataupun di fakultas.

b. Meskipun telah menerima dengan terbuka, masih muncul sikap dari komunikan yang kurang sadar atau terbebani dan kerepotan untuk mengupdate progresifitas $\mathrm{P} 2 \mathrm{M}$ setiap saat di laman IRIS1103.

\section{SIMPULAN DAN SARAN}

Berdasarkan hasil pembahasan yang telah diuraikan di atas maka dapat dikemukakan simpulan sebagai berikut:

Pertama, konteks pelaksanaan kegiatan sosialisasi IRIS1103 yang meliputi latar belakang, tujuan dan perencanaan kegiatan diimplemetasikankan dalam penyusunan pesan yang berisi informasi mengenai IRIS1103.Pesan yang disampaikan narasumber/komunikator sosialisasi IRIS1103 mudah dipahami dan dimengerti oleh audience atau komunikan.Dengan demikian tujuan sosialisasi yakni memperkenalkan IRIS1103 kepada civitas akademika UNS telah terwujud.Dalam hal ini, audience menjadi lebih tahu dan paham tentang IRIS1103, bagaimana pengoperasiannya serta manfaatnya.

Kedua, input penyelenggaraan sosialisasi IRIS1103 adalah sumber daya manusia yang 
berkontribusi melaksanakan kegiatan tersebut khususnya narasumber/komunikator, pihak yang menyampaikan pesan-pesan mengenai aplikasi IRIS1103 kepada audience.Dalam hal ini kredibilitas komunikator menjadi kunci utama keberhasilan atau efektivitas sosialisasi IRIS1103. Kredibilitas komunikator yang dicermati dari otoritas, good sense, good character, good will serta dinamisasi yang dimiliki narasumber atau komunikator IRIS1103 sangat dipercaya audience mampu dan tepat untuk memperkenalkan IRIS1103.

Ketiga, proses sosialisasi IRIS1103 yang dilakukan LPPM UNS bervariasi baik secara langsung (direct) maupun tidak langsung (indirect).Hal ini diupayakan untuk memudahkan sasaran IRIS1103 mengenal, mengetahui dan memahami aplikasi IRIS1103. Sebagai sebuah proses komunikasi, sosialisasi IRIS1103 yang telah dilaksanakan LPPM UNS mengalami alur yang melibatkan komponen komunikasi yakni Komunikator (who) - Pesan (says what) - komunikan (to whom) - Efek/dampak (with what effect) yang secara signifikan mampu mendukung keberhasilan sosialisasi IRIS1103.

Keempat,aspekproduk atau hasil pelaksanaan sosialisasi IRIS1103 dapat dicermati pada fenomen-fenomena yang terjadi pada diri komunikan setelah diterpa pesan mengenai IRIS1103 baik pada tataran kognisi, afeksi maupun behavior. Komunikan menjadi lebih paham dan tahu mengenai IRIS1103, cara pengoperasian dan kemanfaatannya. Mereka juga menerima IRIS1103 dengan senang hati sebagai media pengelolaan P2M yang baik dan mampu merekam jejak P2M yang telah mereka lakukan.Aplikasinya, komunikan mengunjungi laman http://iris1103.uns.ac.id setiap memerlukan informasi mengenai aktivitas P2M.Hal ini menjadi sebuah rutinitas baru bagi komunikan.
Kelima, kegiatan sosialisasi IRIS1103 dapat direkomendasikan untuk dilaksanakan dan dilanjutkan pada tahap berikutnya dengan penambahan atau perubahan pada aplikasi IRIS1103 yang disesuaikan dengan panduan P2M yang juga mengalami perubahan setiap tahunnya. Faktor pendukung dan penghambat pelaksanaan kegiatan sosialisasi IRIS1103 yang dipaparkan peneliti pada pembahasan dapat digunakan sebagai pedoman atau rambu-rambu penyelenggaraan sosialisasi pada tahap selanjutnya.

Dari simpulan di atas,peneliti memiliki beberapa saran yang bisa dijadikan pertimbangan oleh pelaksana sosialisasi IRIS1103 yakni LPPM UNS pada pelaksanaan kegiatan-kegiatan sosialisasi di masa mendatang maupun bagi civitas akademika UNS yang memanfaatkan aplikasi IRIS1103 serta peneliti lain, saran tersebut antara lain:

1. Bagi Pelaksana Sosialisasi IRIS1103

a. Melakukan pembahasan secara kontinyu antara tenaga kependidikan yang bertugas mengadministrasikan aktivitas P2M yang dilakukan tenaga pendidik UNS dengan tim pendesain IRIS1103 untuk memperkuat dan menyempurnakan sistem aplikasi IRIS1103 sesuai dengan kebutuhan penyelenggaraan aktivitas $\mathrm{P} 2 \mathrm{M}$.

b. Perencanaan awal pelaksanaan kegiatan sosialisasi IRIS1103 perlu lebih dimatangkan secara konsep. Perencanaan tersebut dapat disusun berdasarkan analisis situasi yang berkaitan dengan strengthness, weakness, opportunity and treat. Sehingga diperoleh formulasi sosialisasi yang tepat yang dapat digunakan pada tahap selanjutnya

c. Perlu mengkonfirmasi kehadiran peserta sosialisasi melalui telepon setelah 
undangan disampaikan ke fakultas atau unit kerja sebelum sosialisasi dilaksanakan, agar tingkat kehadiran audience dapat maksimal sesuai dengan daftar undangan.

d. Tanggap terhadap saran, dan opini yang terbentuk dari sasaran kegiatan sosialisasi IRIS1103 (dosen) sebagai perbaikan kelanjutan kegiatan sosialisasi IRIS1103.

2. Bagi civitas Akademika UNS

a. Meningkatkan kesadaran akan pentingnya aplikasi IRIS1103 sebagai sarana pengelolaan P2M yang baik.

b. Ikut serta aktif dalam kegiatan sosialisasi IRIS1103 yang diselenggarakan dalam berbagai bentuk kegiatan komunikasi sehingga lebih mengerti dan memahami maksud dari program tersebut.

c. Peduli dengan setiap ketentuan dan kebijakan baru yang berubah dalam aplikasi IRIS1103 yang disesuaikan dengan panduan P2M.

3. Bagi Peneliti Lain

Penelitian ini masih memiliki kekurangan terutama minimnya artikel ilmiah yang terbit di jurnal internasional yang bertopik evaluasi kegiatan komunikasi berdasarkan model evaluasi CIPP sehingga disarankan kepada peneliti lain supaya dapat mengkaji ulang penelitian ini dengan teknik penelitian yang berbeda. Penelitian tersebut bisa berupa penelitian mengenai penyebaran pesan-pesan inovasi IRIS1103 dengan menggunakan teori difusi inovasi ataupun penelitian mengenai kepuasan pengguna IRIS1103 terhadap aplikasi tersebut.

\section{DAFTAR PUSTAKA}

Ardianto, Elvinaro \& Erdinaya, Lukiati Komala.2004. Komunikasi Massa Suatu Pengantar. Bandung. Remaja Rosdakarya

Effendy, Onong Uchjana. 2003. Ilmu Komunikasi Teori dan Praktik. Bandung. Remaja Rosdakarya

Effendy, Onong Uchjana. 2004. Dinamika Komunikasi. Bandung. Remaja Rosdakarya

Harjana, Andre. 2000. Audit Komunikasi Teori dan Praktek. Jakarta.Grasindo

Mulyana, Deddy. 2010. Ilmu Komunikasi Suatu Pengantar Edisi Revisi. Bandung. Remaja Rosdakarya

Pace, R. Wayne \& Faules, Don F. 2013.Komunikasi Organisasi, Strategi Meningkatkan Kinerja Perusahaan. Bandung. Remaja Rosdakarya

Rakhmat, Jalaluddin. 2002. Retorika Modern Pendekatan Praktis. Bandung. Remaja Rosdakarya

Rosfiantika, evi \& Rodiah, Saleha.2015. Strategi Komunikasi Kebijakan Perlindungan dan Pengelolaan Sumber Daya Alam dan Lingkungan Hidup Berdasarkan Kearifan Lokal di Kabupaten Tasikmalaya.Edutech, vol. 1, No. 2, hlm. 273- 290

Suprapto, Tommy \& Fahrianoor.2004. Komunikasi Penyuluhan dalam Teori dan Praktik. Arti Bumi Intaran. Yogyakarta

Wirawan. 2012. Evaluasi Teori, Model, Standar, Aplikasi dan Profesi. Jakarta. Rajawali Pres 